\title{
FEMINIST JURISPRUDENCE AND ITS MANY CORNERS: BUILDING A SOCIO-LEGAL PERSPECTIVE IN THE INDIAN SOCIETY
}

\author{
Raveena S Bhargava \\ Ph.D. Research Scholar, Guru Gobind Singh Indraprastha University, New Delhi, India.
}

\begin{abstract}
This paper tends to explore the various branches of the Feminist Jurisprudence and its inter-section with the other disciplines. To understand the socio-legal nuances involved in the concept of achieving a gender just framework there is a need to analyze the vast scholarly literature available on the subject. Therefore, an attempt has been made to conceptualize the problem of gender inequality existing between the relations of men and women in the Indian society. And finally connecting the scope of this analysis for building a contemporary understanding of the concept of Gender Justice paradigm in the Indian scenario.
\end{abstract}

KEYWORDS: Feminist Jurisprudence, Gender, Gender-relations, Intersectionality, Gender Justice.

\section{INTRODUCTION}

India has witnessed a long-standing history of the Women's Rights movement beginning in the early 1970 s and previous to that, the active involvement of women in the colonial struggle against the imperial British Raj. But researchers also find this kind of an involvement draped in the objective of nationalism than movement for the rights of women in India, per se. The safeguarding of the interests of women through the popular social reform movement led by the middle-class elites during the colonial regime was another attempt, although laced with imperial motives.

The present study is been observed by focusing upon the changing nature of gender relationships existing in the contemporary Indian society. But to understand this transformation process, comprising of the interaction between man and woman amongst each other and with the society at large, it is imperative to lay down a base for appreciating the nuances which stem from the concept of 'gender' itself.

As argued by Cotterrell, "there is need to study both the doctrine, and the social, economic and political contexts of the doctrine, in order to be able to explain how legal change happens. ... While legal scholarship on the whole must broaden its horizons beyond the conventional concerns of the lawyers, there is an equally strong need for engaging scholars from other disciplines to analyse law and legal institutions." The need to carry out this study is etched into a conscientious realization about the changing situations involving 'both' the participantswoman and man. Also, at the same time juxtapose the position of both women and men as citizens of the country, in loss of their fundamental and legal rights in certain exceptional circumstances, with relation to each other. The position of law and idea of gender justice requires a practical re-examination in the contemporary times.

India as a nation has also supported the larger theme of Women Empowerment in the international community. This commitment is reflected through the efforts of the G20 states by ensuring low gender disparity in labour markets. This is not going to be easy because gender disparities are not mechanical but structural in nature. They are based on certain stereotypical assertions and value based social norms prevalent in a particular society. To bring about changes at both national and international levels, holistic approaches to gender equality will be required. At the G20 summit of 
2019, two important themes emerged from the formal deliberations between the countries - the role of women in achieving- a) Sustainable Development Growth, b) Inclusive Economic Growth.

\section{OBJECTIVES}

- To analyse the scholarly literature on Feminist Jurisprudence and utilise it to understand the problem of gender inequality existing in the Indian Society.

- To understand and analyse the concept of gender justice in the contemporary Indian scenario.

\section{METHODOLOGY}

The research has been conducted through a doctrinal method of study.

\section{Gender \& Gender Relations}

The 'biological determinism' has been the primary understanding of the distinction between a human female and a human male. Generally speaking, 'Sex' and 'Gender' are considered to be co-extensive terms. Historically, many theorists have taken a contrary view to explain the differentiation between biological factors - the anatomical difference between a man and a woman (sex organs, chromosomes and other physical features) and the sociological factors like social role, societal position, behaviour and personal identity.

According to some early philosophers, the physical disposition of person played a vital role in deciding his or her social, psychological and behavioural traits (Geddes \& Thompson, 1889). For instance, women are considered to be anabolic based on their metabolic rate, making them passive and conservative. On the other hand, men are considered to be katabolic, making them passionate and such a physiological distinction was used not only to decipher behavioural roles amongst men and women but also to largely guide their social and political arrangements. "What was decided among the prehistoric Protozoa cannot be annulled by Act of Parliament" (Moi 1999, 18).

The understanding and perception of 'sex' and 'gender' has diversified over a period of time. The inclusion of the question of gender, over a due course of time, started locating itself in many interdisciplinary studies.

\section{Gender and Patriarchy}

"Since patriarchy is so universal, it cannot be the product of some vicious circle that was kickstarted by a chance occurrence. It is particularly noteworthy that even before 1492, most societies in both America and Afro-Asia were patriarchal, even though they had been out of contact for thousands of years." (Harari, 2015). If patriarchy in Afro-Asia resulted from some chance occurrences, why were the Aztecs and Incas patriarchal? It is far more likely that even though the precise definition of 'man' and 'woman' varies between cultures, there is some universal biological reason why almost all cultures valued manhood over womanhood. We do not know what this reason is. There are plenty of theories, none of them convincing.

Kumkum Roy, in her study of ancient India argues that it was "the privileging" of the household space, also known as griha in Hindi language that "was characterized by patriarchal control, exercised on the procreative powers of the wife, and over productive resources, which were ideally transferred from the father to the son(s)". The same pattern of domesticity is prevalent in the current patriarchal order and also recognised by the personal laws of the country.

As per theoretical understanding on the subject matter, patriarchy is understood in context of the dominance of the highest male member of the family who is the decision maker of the house. The literal meaning of the word as per the Women's Studies Encyclopedia means "the rule of the father". Later on, through the development of feminist discourses in the west, patriarchy as a social phenomenon was understood to explain male dominance in different facets of life. It was not only based on biology of the sexes rather on based upon the sociological factors.

It is relevant to note that "such pre-feminist usage first focused on hierarchical relations among men in legal, political, and economic terms, whereas male authority over women holds a second place, until feminist scholarship brought the structural domination of women in such systems to the forefront" (Dialeti, 2013). Smuts (1995) found "evolutionary psychology posits that certain behaviours are universal because they helped the genes of a particular species to survive across the generations. In the case of human beings, such behavioural predispositions evolved to adapt us to the Stone Age rather the modern world. Patriarchy, we suggest, has deep roots in human evolution."

Potts \& Campbell (2008) stated "Darwin was the first person to understand that men and women can have different reproductive agendas for explicable biological reasons." It is significant to note that what Darwin called the "war of nature" to also exist between the "two sexes of the same species".

It was also found by Darwin (1871) that "the male ... seems to owe his greater size to his ancestors having fought with other males during many generations".

At the same time, the academic disciplines such as gender studies or women's development studies no longer take into account patriarchy as a single reference point to understand the multi-faceted nature of gender-relations existing between sexes. "Once a term debated in endless articles, conferences 
and books, many theorists now regard it is as too blunt and monolithic to capture the nuances of oppression" (Higgins,2018).

Patriarchy as a concept has been seemingly the cornerstone that brings together disparate events experienced by different women across different cultures and backgrounds. Srinivasan notes, "It allows people to ask whether some machine is at work that connects all the experiences they're having with all the experiences others are having." In her book, Coward (1983), puts forward some pressing questions - "Patriarchy as a concept brings forth an account of the history of sexual relations but at some point, the same question has to be asked: Why was it that men took control and what purpose does it serve? Leading back to the conundrum of natural sexual differences, in which sexes have different interests by nature or are the sexual relations or dispositions are a product of patriarchal structure itself?" Hence, different corners of feminist discourse have tried to both appreciate and detest such pertinent questions so as to answer them in context of practical social situations faced by men and women living in the society.

A near objective study of the feminist's interest in the subject matter of gender relations has led us to adopt two very stark propositions. As Mary Wollstonecraft (1792), a classical liberal feminist would have it, "as men are not defined by their bodies, nor should women be." On the other hand, a feminist might reject the above idea completely and have it the other way round, as women we should hold onto the peculiarity of feminine qualities.

\section{Gender \& Masculinity}

Genevieve Llyod (1993) in her book, The

Man of Reason said, "But the symbolic content of maleness and femaleness cannot be equated with socially produced masculinity and femininity. The symbolic content interacts with the socially constructed gender."

Natalie Davis as early as 1975, suggested, "It seems to me that we should be interested in the history of both women and men, that we should not be working only on the subjected sex any more.... Our goal is to understand the significance of the sexes, of gender groups in the historical past. Our goal is to discover the range in sex roles and in sexual symbolism in different societies and periods, to find out what meaning they had and how they functioned to maintain the social order or to promote its change." The early feminist scholars were of the opinion that a critical re-examination of the existing scholarship of the subject matter would lead to enlarging of the traditional notions of historical significance. "Such a methodology implies not only a new history of women, but also a new history" (Gordon, et.al. 1976).
According to Brod and Kaufman (1994) the research on masculinity is mainly informed by a feminist outlook. "A power relationship exists between men of different classes, aces and abilities, in addition to the power relationship which exists between men and women" (Hearn \& Collinson 1994). Connell (1993) put focus on "men's role as economic providers" which according to her, "comes from a polarised model of gender relations rooted in Northern industrialisation, of a male breadwinner with a wife who performs unpaid domestic work in the home, and ideals of physical strength, and solidarity between male workmates forged through struggles with managers." The amalgamation of the exported ideas from colonialism, travelling into the local and social spheres of the people's life, with the idea of masculinity lead to certain structural changes. Cornwall and Lindisfarne stated, "masculinities imported from elsewhere are conflated with local ideas to produce new configurations".

As mentioned above, the 'gender' question is directly related to the personal identity of an individual. Not only that most men may not accept or associate themselves with women's work it is also the women who do not ascribe to the idea of men performing roles that are associated with women generally (Engle \& Leonard1995). "One compelling view is that changes in gender roles in the private sphere will only occur when domestic work and childcare cease to be seen as low-status occupations" (Willott \& Griffin, 1996). Many writers have discussed the tripartite classification of the 'fatherly' role adorned by men, i.e., the biological role as father, taking up economic responsibility of the family and lastly, being "social fathers". The first two aspects are viewed important cross culturally.

The early feminism casted men as 'the problem', side lining those attributes which are culturally viewed as masculine associated with men. As Cornwall, 2000 states, "not only were they told that they should give up positions that put them at an advantage, they were left without anything to value about being men." She further explains, "by disregarding the complexities of male experience, by characterising men as 'the problem', and by continuing to focus on women-in-general as 'the oppressed', development initiatives that aim to be 'gender-aware' can fail to address effectively the issues of equity and empowerment that are crucial in bringing about positive change".

The concept of Gender and Development "offered a new approach to including women in the development process; gender training became a 'means by which feminist advocates and practitioners... [sought] to de-institutionalise male privilege within development policy and planning" (Kabeer, 1995). The gender analysis has helped us in providing with the tools to study and understand the material bases of difference that exist between men 
and women, yet it has not provided us with an insight to actually understand- what difference in gender roles and identities exist individually, for these men and women, within their social communities.

\section{The Concept of Gender Justice}

Socio-legal discourses in India concerned with gender rights have gone through a tremendous change in the past few decades. While an important shift can be seen in the women and law scholarship in the recent past, this subject-matter has been explored by legal scholars as well as sociologists, historians, political scientist who have initiated some of the most important changes in the socio-legal analysis of the women's issues.

According to contemporary scholars, progressiveness in matters relating to marriage and intimate relationships does not lie in organizing the society on the basis of an unilinear approach. Rather it lies on principles such as the following: first, allowing every person, especially women, to organize personal relationships by their individual freedom and choice, for instance, not just based on what is prescribed by the personal laws. Second, imparting legal validity to these individual choices and third, having a rights-based framework to protect the rights of women. According to Oxfam, "Gender justice is a human right" wherein every woman and girl is entitled to live with dignity. "It is necessary to maintain gender justice in the society for the development of the masses, poverty reduction and crucial for human progress" (Rai \& Paul, 2020).

\section{CONCLUSION}

The focus in terms of gender studies, feminist legal theories and feminist jurisprudence showcases a trajectory of various social changes that have marked a shift in understanding the scope and extent of gender-relations in the Indian society. The analysis of this evolutionary process can help legal theorists and legal practitioners to help build a better perspective in terms of legal policy formulation.

\section{REFERENCES}

1. Malhotra, S.R. Schuler, et.al. "Measuring women's empowerment as a variable in internationaldevelopment" The World Bank, Washington D.C.

2. Andrea Cornwall, "Men, masculinity and 'gender in development'," in Carolina Sweetman, Men and Masculinity Oxfam Focus on Gender 8-13 (Oxfam GB,2000).

3. Andrea Cornwall Men, masculinity and 'gender in development' available at: https://oxfamilibrary.openrepository.com/bitstrea $\mathrm{m} /$ handle/10546/121126/bk-men-andmasculinity-010197en.pdf? sequence $=1 \&$ isAllowed $=y$

4. Ann D. Gordon, Mari Jo Buhle, and Nancy Shrom Dye, "The Problem of Women's History", in Berenice Carroll, ed., Liberating Women's History 89 (Urbana III, 1976).

5. Charlotte Higgins, The age of patriarchy: how an unfashionable idea became a rallying cry for feminism today available at: https://www.theguardian.com/news/2018/jun/22/t he-age-of-patriarchy-how-an-unfashionableidea-became-a-rallying-cry-for-feminism-today (last visited on May 6,2020).

6. Chant, S. "'From 'Woman-Blind' to 'Man-Kind': Should Men Have More Space in Gender and Development?" IDS Bulletin Vol 31, pages 7 -17 (2000).

7. Connell, R.W., Masculinities, 44 (University of California Press, 1995).

8. Caroline Sweetman (ed.), Men and Masculinity Oxfam Focus on Gender available at: https://oxfamilibrary.openrepository.com/bitstrea $\mathrm{m} / \mathrm{handle} / 10546 / 121126 / \mathrm{bk}$-men-andmasculinity-010197en.pdf? sequence $=1$ \&isAllowed $=y$

9. Darwin C. The Descent of Man and Selection in Relation to Sex. First edition published in 1871.

10. Gender Justice as an International Objective: India in the G20 available at: https://www.gigahamburg.de/en/publication/gender-justice-as-aninternational-objective-india-in-the-g20

11. John Wiley \& Sons. pp. 441-442. ISBN 978-14051-8353-6.

12. Joan W. Scott, "Gender: A Useful Category of Historical Analysis", 91 The American Historical Review 1054 (1986).

13. Jane K. Cowan, Marie-Bénédicte Dembour, and Richard A. Wilson, eds., Culture and Rights: Anthropological Perspectives (Cambridge; New York: Cambridge University Press, 2001); Anthony O'Hear, "Culture," Routledge Encyclopaedia of Philosophy (Taylor and Francis, 1998).

14. Kumkum Sangari and Sudesh Vaid (eds.), Recasting Women Essays in Colonial History 2-3 (kali for women, Delhi, 1989).

15. Klasen, Stephan, and Francesca Lamanna. 2009. "The Impact of Gender Inequality in Education and Employment on Economic Growth: New Evidence for a Panel of Countries." Feminist Economics 15(3): 91-132. available at: doi: 10.1080/13545700902893106 (last visited on April 13, 2020)

16. K. Roy, The Emergence of Monarchy in North India: Eighth to Fourth Centuries B.C. (New Delhi: Oxford University Press, 1994), 300.

17. M. Bose (ed.), Faces of the Feminine in Ancient, Medieval, and Modern India 4-5 (Delhi: Oxford University Press, 1999).

18. Malcolm Potts, Martha Campbell "The origins and future of patriarchy: the biological background of gender politics" 34(3) Fam Plann Reprod Health Care 171 (2008).

19. Maheema Rai and Salvin Paul, "Exploring Gender Justice for Attaining Equality" Gender Equality 266-276 (Springer Nature Switzerland $A G, 2020)$.

20. Rosalind Coward, author of Patriarchal Precedents: Sexuality and Social Relations (1983) 
EPRA International Journal of Multidisciplinary Research (IJMR) - Peer Reviewed Journal

Volume: 7| Issue: 12| December 2021|| Journal DOI: 10.36713/epra2013 || SJIF Impact Factor 2021: 8.047 || ISI Value: 1.188

21. Smuts B. The evolutionary origins of human patriarchy. Hum Nature 1995; 6: 1-32.

22. Sally Davies, Women's minds matter available at: $\quad$ https://aeon.colessays/feminists-neverbought-the-idea-of-a-mind-set-free-from-its-body (last visited on May 9, 2020).

23. Sarah $C$ White "Men, masculinities, and the politics of development", in Carolina Sweetman, Men and

24. Masculinity Oxfam Focus on Gender 14-22 (Oxfam GB,2000).Tierney, Helen (ed.). Women's Studies Encyclopedia, Volume 2

25. The Man of Reason: "male" and "female" in Western philosophy, second edition published in 1993 by Routledge 11 New Fetter Lane, London EC4P 4EE. 